\title{
Сучасні напрями діяльності кінноспортивних клубів: зарубіжний та вітчизняний досвід
}

\author{
Наталія Шмаренкова
}

Національний університет фрізичного виховання і спорту України, Київ, Україна

Анотація. Здійснено узагальнення та систематизацію основних напрямів діяльності кінноспортивних клубів в Україні та за кордоном. Мета. Узагальнення та систематизація основних напрямів діяльності кінноспортивних клубів в Україні та за кордоном. Методи. Статистичний, порівняльного аналізу, систематизації. Результати. Представлена систематизація основних напрямків діяльності кінноспортивних клубів в Україні показала, що на сьогодні в Україні існують: 1) великі кінноспортивні клуби - суб'єкти, які задіяні за основною (в тому числі з організацією та проведенням кінноспортивних турнірів, змагань як національних, так і міжнародних) та додатковою діяльністю; 2) середні кінноспортивні клуби - суб'єкти, які надають широкий спектр основних та додаткових послуг, але не займаються організацією та проведенням кінноспортивних турнірів, змагань (через відсутність критих майданчиків); 3) малі кінноспортивні клуби - суб'єкти, які надають вузький спектр послуг. Аналіз та систематизацію основних напрямів діяльності кінноспортивних клубів в інших країнах здійснено на прикладі країн, які протягом останніх 20 років мали перемоги та були лідерами Олімпійських ігор з кінного спорту. Встановлено, що кінноспортивні клуби цих країн, як і українські, пропонують послуги основного та додаткового напрямів діяльності. При цьому вагоме місце в їх функціонуванні займають ті послуги, які забезпечують попит серед населення, дохідність (участь в тоталізаторах на скачках, які осріційно дозволені законодавством). Встановлено, що цей вид діяльності є важливим джерелом доходів як кінноспортивних клубів, так і бюджету країн. Можна констатувати, що адаптація кращого зарубіжного досвіду управління напрямами діяльності в Україні можлива за умов відповідного законодавчого та інституційного забезпечення. Дохідний напрям участі кінноспортивних клубів у тоталізаторах на скачках потребує прийняття рішення на рівні державної влади щодо необхідності та можливості дозволу на такий вид діяльності. Розвиток організаційно-технічного потенціалу, необхідного для розширення масштабів діяльності кінноспортивних клубів, може бути реалізований за умов паритетного державно-приватного партнерства, зокрема за напрямом відкриття закладів з підготовки кадрів та відкриття і реконструкції іподромів тощо.

Ключові слова: кінноспортивні клуби, напрями діяльності, надання послуг.

\section{Natalia Shmarenkova}

\section{MODERN DIRECTIONS OF HORSE-RACING CLUB ACTIVITY: FOREIGN AND DOMESTIC EXPERIENCE}

Abstract. The main directions of horse-racing club activity in Ukraine and abroad have been generalized and systematized. Objective. Generalization and systematization of the main activities of horse-racing club in Ukraine and abroad. Methods. Statistical, comparative analysis, systematization. Results. The presented systematization of the main activities of horse-racing clubs in Ukraine showed that today there are: 1) large horse-racing clubs - entities that are involved in the main (including the organization and conduct of equestrian tournaments, competitions, both national and international ) and additional activities; 2) medium clubs - entities that provide a wide range of basic and additional services, but do not organize and conduct equestrian tournaments, competitions (due to the lack of indoor areas); 3) small clubs - entities that provide a narrow range of services. The analysis and systematization of the main activities of horse-racing clubs in other countries was made on the example of countries that had great victories in the last 20 years and were leaders of the Olympic Games in equestrian sports. It is established that horse-racing clubs of these countries, as well as Ukrainian, offer services of the main and additional directions of activity. At the same time, an important place in their functioning belongs to those services that provide demand among the population, profitability (participation in sweepstakes at races, which are officially allowed by law). It is established that this type of activity is an important source of income for both the clubs and the budget of the countries.

Shmarenkova N. Modern directions of horse-racing club activity: foreign and domestic experience. Theory and Methods of Physical education and sports. 2020; 3 : 50-55 DOI: $10.32652 /$ tmfvs.2020.3.50-55
Шмаренкова Н. Сучасні напрями діяльності кінноспортивних клубів: зарубіжний та вітчизняний досвід. Теорія і методика фрізичного виховання і спорту. 2020; 3: 50-55

DOI: 10.32652/tmfvs.2020.3.50-55
Вступ. Важливим завданням сучасної науки у сорері управління спортивно-дозвільними закладами й установами $€$ вивчення і узагальнення тенденцій досвіду розвитку напрямів діяльності вітчизняних та зарубіжних суб'єктів функціонування. Це великий пласт знань, теоретично-практичних аспектів, що охоплюють напрями основної та додаткової діяльності, яка дозволяє працювати цим організаціям у складних економічно-ринкових умовах. Вказане стосується і закладів, установ, підприємств кінноспортивної сфери, де від оптимального вибору та організації напрямів діяльності залежить успіх на ринку та економічна незалежність, можливість отримання прибутку, покриття широкого спектра витрат, пов'язаних з утриманням персоналу, коней, технічними, адміністративними, іншими господарськими потребами тощо. Зважаючи на сказане, обрана тема дослідження $€$ актуальною.

Питання вивчення проблеми розвитку напрямів діяльності закладів, установ, підприємств кінноспортивної сорери вивчали зарубіжні та вітчизняні дослідники (І. Ткачева, А. Нагнебальна, М. Вінцевіч-Босий, аналітики, що розглядали вказаний аспект дослідження). Воно висвітлене в статистичних даних. 3 огляду на зміни, що відбуваються в даній сфері, $є$ потреба аналізу та систематизації цих трансформацій та встановлення фрактичного стану за вказаною проблематикою.

Мета дослідження - узагальнення та систематизація основних напрямів діяльності кінноспортивних клубів в Україні та за кордоном.

Методи дослідження: статистичний, порівняльного аналізу, систематизації тощо.

Результати дослідження та їх обговорення. Сучасний ріст урбанізації, погіршення екології, переважання сидячого способу життя більшої частини населення впливають на збільшення попиту на дозвільні спортивнооздоровчі заняття, що передбачають 
It can be stated that the adaptation of the best foreign experience in the management of activities in Ukraine is possible under the conditions of appropriate legislative and institutional support. The lucrative direction of clubs' participation in sweepstakes at races requires a decision at the level of state power on the need and possibility of permission for this type of activity. The development of organizational and technical potential needed to expand the activities of horse-racing clubs can be realized under conditions of parity public-private partnership, in particular in the direction of opening training facilities and opening and reconstruction of race courses, etc. Keywords: horse-racing clubs, activity directions, service provision. вихід на природу, в тому числі верхову їзду. У зв'язку з цим певної актуальності на сьогодні набуває розвиток, вдосконалення організації діяльності кінноспортивних клубів, розширення напрямів їх діяльності. Науковий інтерес представляють напрями діяльності, які забезпечують функціонування таких організацій у зарубіжній та вітчизняній практиці. Вивчення кращих зарубіжних підходів до вибору напрямів діяльності $є$ важливою запорукою адаптації у вітчизняну роботу кінноспортивних клубів.

Розглянемо основні напрями діяльності кінноспортивних клубів в Україні на сучасному етапі розвитку цієї сфрери. На рисунку 1 подано динаміку змін кількості кінноспортивних клубів в Україні за 2000-2018 рр. Вивчення статистичних даних свідчить, що за період 2000-2018 рр. кількість кінноспортивних клубів в Україні зросла на 24 одиниці (82,8 \%) і наприкінці 2018 р. становила 53 одиниці. Найбільш стрімкий ріст цих організацій спостерігався за період 2005-2010 рр. (на 24 одиниці). В цей час в Україні збільшилась кількість інвестицій у зазначену сфреру, зріс попит на верхову їзду серед населення під впливом зростання економічного добробуту.

Аналіз статистичної інфрормації свідчить, що найбільш складним для даної ссрери можна назвати 2014 р., коли в країні через військово-політичні події відбулося суттєве скорочення кінноспортивних клубів (з 61 одиниці у 2013 р. до 50 одиниць у 2014 р.). Переважно, це стосувалось певних територій Донецької та Луганської областей, AP Крим. 3 кінця 2015 р. почала стабілізуватись ситуація щодо функціонування цих суб'єктів господарювання, відбулось певне зростання та збільшення масштабів діяльності (3 48 одиниць у 2015 р. до 53 одиниць у 2018 р.). Покращення розвитку вказаних суб'єктів пов'язане 3 покращенням соціальноекономічного стану громадян.

Слід відмітити нерівномірність регіонального розташування кінноспортивних клубів в Україні (табл. 1). Є три регіони 3 найбільшою концентраці$є ю$ кінноспортивних клубів: Дніпропетровська, Київська обл., м. Київ (по шість суб'єктів господарювання). Також вагоме місце в розвитку кінноспортивної сфери займає Запорізька обл. (п'ять кінноспортивних клубів). Інші регіони не вирізняються високим рівнем розвитку кінноспортивних клубів, що пов'язано з інвестиційними проблемами, недостатньою готовністю бізнес-середовища до створення таких проєктів через відсутність досвіду.

Окремо слід відмітити, що кінноспортивні клуби м. Києва, Київської обл. мають кращі організаційно-тех-

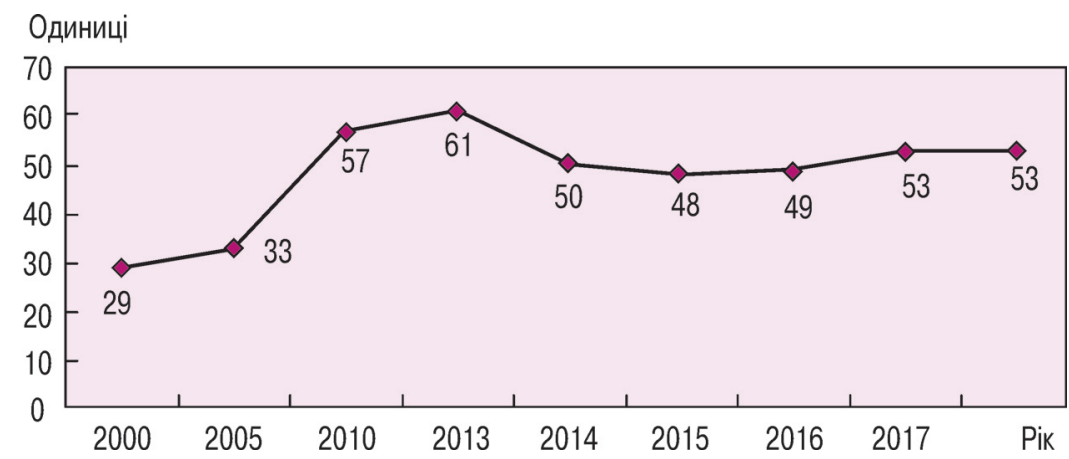

Рисунок 1 - Кількість кінноспортивних клубів в Україні за 2000-2018 рр. [за: 7; 11] нічні умови, зокрема, у семи клубах $є$ криті майданчики, що підвищує їх привабливість з точки зору організації турнірів, змагань, у тому числі міжнародних [8]. Відповідно, вказані організаційнотехнічні переваги є умовою розвитку такого напряму діяльності, як організація та проведення турнірів, змагань, у тому числі міжнародних.

Вивчення наукових, аналітичних та статистичних матеріалів дозволи-

Т а б л и ц я 1. Кількість кінноспортивних клубів України за регіонами станом на 31.12.2018 р. [3а: 7, 11]

\begin{tabular}{|c|c|c|}
\hline № $3 / п$ & Perioh & Кількість \\
\hline 1 & Вінницька обл. & 0 \\
\hline 2 & Волинська обл. & 0 \\
\hline 3 & Дніпропетровська обл. & 6 \\
\hline 4 & Донецька обл. & 2 \\
\hline 5 & Житомирська обл. & 1 \\
\hline 6 & Закарпатська обл. & 0 \\
\hline 7 & Запорізька обл. & 5 \\
\hline 8 & І̇вано-Франківська обл. & 0 \\
\hline 9 & Київська обл. & 6 \\
\hline 10 & Кіровоградська обл. & 1 \\
\hline 11 & Луганська обл. & 1 \\
\hline 12 & Львівська обл. & 2 \\
\hline 13 & Миколаївська обл. & 1 \\
\hline 14 & Одеська обл. & 4 \\
\hline 15 & Полтавська обл. & 3 \\
\hline 16 & Рівненська обл. & 2 \\
\hline 17 & Сумська обл. & 2 \\
\hline 18 & Тернопільська обл. & 0 \\
\hline 19 & Харківська обл. & 1 \\
\hline 20 & Херсонська. обл. & 2 \\
\hline 21 & Хмельницька обл. & 1 \\
\hline 22 & Черкаська обл. & 3 \\
\hline 23 & Чернівецька обл. & 1 \\
\hline 24 & Чернігівська обл. & 1 \\
\hline 25 & м. Київ & 6 \\
\hline 26 & АР Крим & 0 \\
\hline 27 & м. Севастополь & 0 \\
\hline & Разом & 53 \\
\hline
\end{tabular}


Т а б л и ц я 2. Систематизація напрямів діяльності кінноспортивних клубів України станом на 31.12 .2018 р. [за: 2-5, 8, 10]

\begin{tabular}{|c|c|c|c|c|}
\hline \multirow{2}{*}{ № $3 / n$} & \multirow{2}{*}{ Напрями та види діяльності } & \multicolumn{3}{|c|}{ Кінноспортивні клуби } \\
\hline & & $\begin{array}{c}\text { Великі (в тому числі } \\
\text { з критими майданчиками) }\end{array}$ & $\begin{array}{l}\text { Середні, } 3 \text { широким } \\
\text { спектром послуг }\end{array}$ & $\begin{array}{l}\text { Малі, з вузьким } \\
\text { спектром послуг }\end{array}$ \\
\hline I & Основна діяльність & & & \\
\hline 1 & Послуги тренування & $+1-$ & $+1-$ & $+1-$ \\
\hline 2 & Послуги катання на конях & $+1-$ & $+/-$ & $+/-$ \\
\hline 3 & Послуги навчання верхової їзди & $+1-$ & $+1-$ & $+/-$ \\
\hline 4 & Послуги оренди клубних коней & $+1-$ & $+1-$ & $+1-$ \\
\hline 5 & Послуги (пакет) пансіону для коней & $+1-$ & $+1-$ & $+1-$ \\
\hline 6 & Послуги ветеринарного лікаря & $+1-$ & $+1-$ & $+1-$ \\
\hline 7 & Послуги коняра & $+1-$ & $+1-$ & $+1-$ \\
\hline 8 & Послуги вершника & $+1-$ & $+1-$ & $+1-$ \\
\hline 9 & Послуги прокату амуніції та аксесуарів & $+1-$ & $+1-$ & $+1-$ \\
\hline 10 & Послуги продажу амуніції та аксесуарів (магазин) & $+1-$ & $+1-$ & $+1-$ \\
\hline 11 & $\begin{array}{l}\text { Послуги підготовки та тренування коней (комплексно } \\
\text { з урахуванням роботи коняра, вершника, ветеринар- } \\
\text { ного лікаря) }\end{array}$ & $+1-$ & $+1-$ & $+1-$ \\
\hline 12 & Послуги з продажу коней & $+1-$ & $+1-$ & - \\
\hline 13 & $\begin{array}{l}\text { Організація та проведення кінноспортивних турнірів, } \\
\text { змагань, у тому числі міжнародних }\end{array}$ & + & - & - \\
\hline 14 & $\begin{array}{l}\text { Організація прогулянок (походів) на конях (разові по- } \\
\text { слуги) }\end{array}$ & $+/-$ & $+1-$ & $\begin{array}{c}+ \text { / - (найбільш ча- } \\
\text { сто) }\end{array}$ \\
\hline 15 & Організація святкових заходів за участю коней & $+1-$ & $+1-$ & $+1-$ \\
\hline 16 & Послуги іпотерапії & $+1-$ & $+/-$ & $+/-$ \\
\hline$\|$ & Додаткова діяльність & & & \\
\hline 16 & Послуги розміщення & $+1-$ & $+/-$ & $+1-$ \\
\hline 17 & Послуги харчування & $+1-$ & $+1-$ & $+1-$ \\
\hline 18 & Послуги паркування автомобілів & $+1-$ & $+1-$ & $+/-$ \\
\hline 19 & $\begin{array}{l}\text { Послуги оренди приміщень, території під певні за- } \\
\text { ходи }\end{array}$ & $+1-$ & $+1-$ & $+/-$ \\
\hline 20 & Послуги догляду за дітьми різного віку & $+1-$ & $+/-$ & $+1-$ \\
\hline 21 & Їнші додаткові послуги & $+1-$ & $+1-$ & $+1-$ \\
\hline
\end{tabular}

ло розробити систематизацію напрямів діяльності кінноспортивних клубів України станом на 31.12.2018 р. (табл. 2). Аналіз представлених результатів показав, що на сьогодні в Україні існують:

1) великі кінноспортивні клуби (в тому числі з критими майданчиками), які задіяні за основною (в тому числі з організацією та проведенням кінноспортивних турнірів, змагань як національних, так і міжнародних) та додатковою діяльністю. До них можна віднести: дитячу школу верхової їзди «Конюшня Бутенко» (с. Проців, Київська обл.), кінноспортивний клуб «Equides» (Київська обл., с. Лісники), кінноспортивний комплекс «Parade Allure» (Черкаська обл., м. Жашків), кінноспортивний комплекс «Магнат» (Київська обл., с. Чубинське), сімейний кінний клуб «DERGACHOV» (Київська обл., Обухівський р-н, с. Верем'я). Ці клуби зазвичай пропонують більшість видів основної та додат- кової діяльності, зокрема, широкий спектр послуг;

2) середні кінноспортивні клуби, які надають широкий спектр основних та додаткових послуг, але не займаються організацією та проведенням турнірів і змагань (через відсутність критих майданчиків).

Це середні за масштабами діяльності кінноспортивні клуби, розміщені в Донецькій, Запорізькій, Київській (деякі, що не належать до категорії вели- 
ких клубів), Львівській, Одеській, Полтавській обл. Вказані клуби мають перспективи розвитку у разі інвестування;

3) малі кінноспортивні клуби, які надають вузький спектр послуг. Вказані послуги можуть надаватися як за основним, так і частково за додатковим напрямом діяльності. Такі клуби часто пропонують послуги з організації прогулянок (походів) на конях (разові послуги). Можна зауважити, що це суб'єкти господарювання з невеликими обсягами діяльності.

Вивчення статистики медального заліку останніх Ігор Олімпіад свідчить, що Україна не демонструвала високих досягнень. Найбільше перемог на Олімпійських іграх за весь період їх проведення мали Німеччина, Швеція, Франція, США, Велика Британія [6]. Україна має певні переваги на інших міжнародних турнірах. Незважаючи на відсутність вагомих перемог у міжнародному кінному спорті, українські клуби своєю діяльністю забезпечують розвиток та відновлення рухової активності населення. Хоча розвиток кінноспортивних клубів України не може вважатися ефективним через ряд організаційнотехнічних, фрінансово-кредитних, управлінських, кадрових внутрішніх та зовнішніх факторів впливу (великою мірою соціально-економічного стану населення) [12].

Розглянемо основні напрями діяльності кінноспортивних клубів у країнах, які досягли результативності в олімпійському медальному заліку станом на 31.12.2018 р. На рисунку 2 представлено чисельність кінноспортивних клубів Німеччини (1-ше місце), Швеції (2-ге місце), Франції (3-тє місце) та Польщі (17-те місце) та працівників, зайнятих в їх діяльності. Відповідно до результатів дослідження, можна констатувати, що такі лідери у сфрері кінного спорту, як Німеччина і Франція мають велику кількість кінноспортивних клубів з відповідно великим ринком праці. Швеція, хоча і знаходиться на другому місці в олімпійському медальному заліку, має 900 кінноспортивних клубів з 10000 зайнятих працівників. Польща, яка посідає 17-те місце в олімпійському медальному заліку за останні двадцять років, має достатньо розвинену мережу кінноспортивних клубів, рівномірно розташованих на всій території країни.

Зважаючи на зростання попиту з боку населення до занять верховою

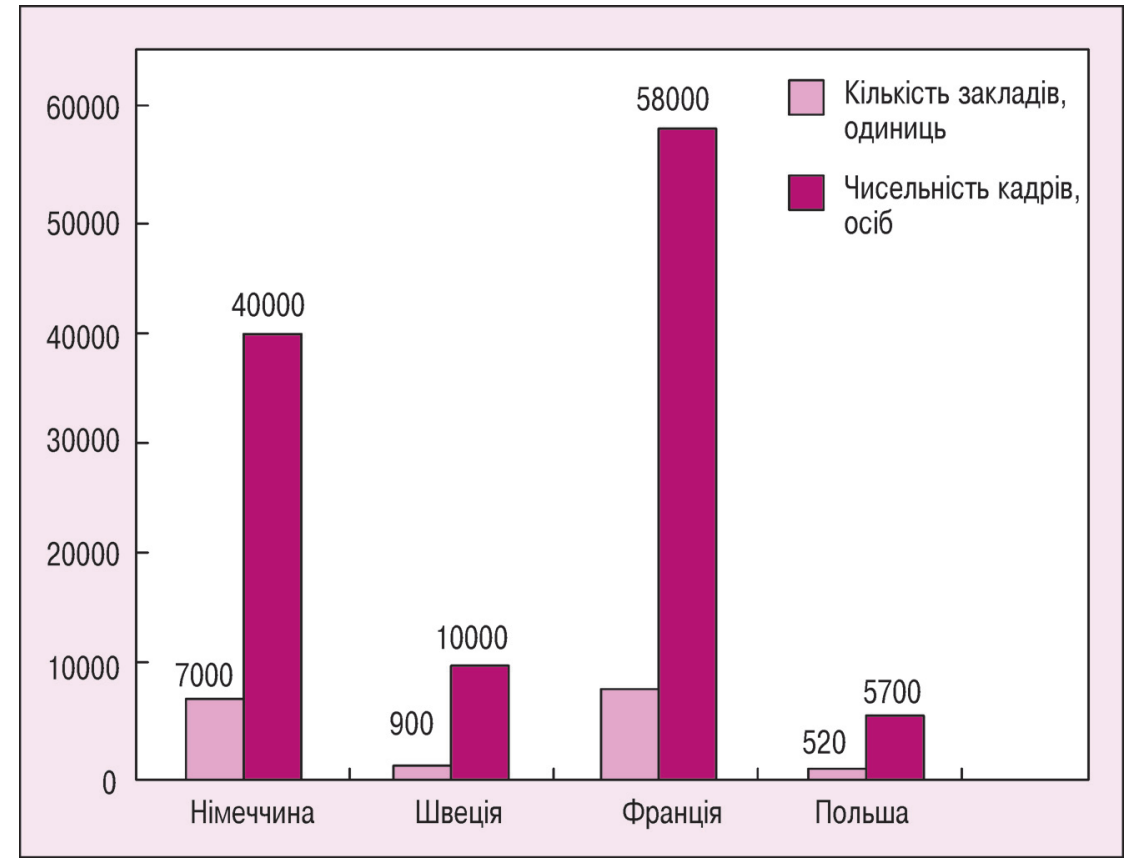

Рисунок 2 - Чисельність кінноспортивних клубів зарубіжних країн та працівників, зайнятих в їх діяльності станом на 31.12 .2018 р. [за: 12; 13; 15; 16]

їздою, участі країни в міжнародних змаганнях, турнірах 3 кінного спорту, в Польщі за період 2014-2018 рр. стрімко зросла мережа цих закладів (рис. 3): якщо в 2014 р. їх було 420, то в 2018 р. -520 .

Важливим аспектом успішного розвитку кінноспортивних клубів у країнах, які досягли результативності в олімпійському медальному заліку, $€$ ефективний вибір напрямів та видів діяльності. На основі вивчення наукових, аналітичних та статистичних матеріалів було створено систематизацію основних напрямів діяльності кінноспортивних клубів цих країн станом на 31.12.2018 р. (табл. 3). Оцінка результатів систематизації дозволяє констатувати, що:

1) у чотирьох досліджуваних країнах кінноспортивні клуби пропонують широкий спектр послуг за напрямом основної діяльності. При цьому значне поширення в Німеччині і Франції мають: послуги тренування, навчання верхової їзд (школи при клубах), пансіону для коней, організація та проведення кінноспортивних турнірів, змагань, у тому числі міжнародних, кінні табори для дітей, кінні перегони (офіційно дозволений тоталізатор).

Схожий перелік найбільш поширених послуг за основним напрямом ді- яльності мають кінноспортивні клуби Швеції, за винятком того, що в цій країні менше шкіл верхової їзди при клубах. У Польщі схожа картина розвитку кінноспортивних клубів, хоча, порівняно 3 іншими країнами, в державі немає такого високого рівня та досвіду організації і проведення кінноспортивних турнірів, змагань, у тому числі міжнародних. Усі країни забезпечують дохід у цій сорері від участі в тоталізаторах на скачках, наприклад, у Франції, щорічний дохід становить 12-14 млрд євро $[1,9]$. Порівняно з Україною, в цих країнах офріційно легалізовано ігорний бізнес і тоталізатори на скачках також. В Україні існує тіньова практика проведення таких тоталізаторів, в результаті

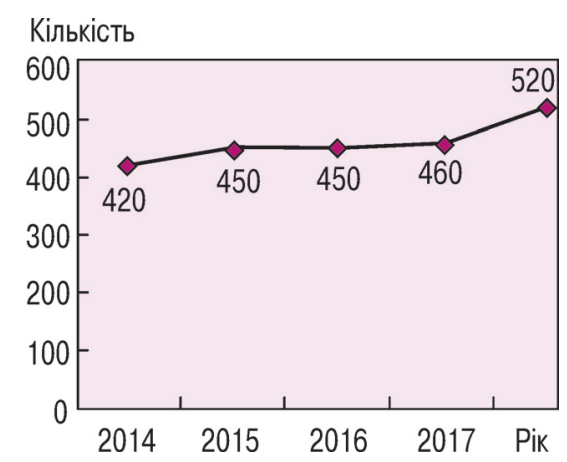

Рисунок 3 - Динаміка змін кількості кінноспортивних клубів Польщі за період 2014-2018 рр. [за: 14] 
Т а б л и ц я 3. Систематизація основних напрямів діяльності кінноспортивних клубів Німеччини, Швеції, Франції та Польщі станом на 31.12.2018 р. [за: 12-16]

\begin{tabular}{|c|c|c|c|c|c|}
\hline № $3 / n$ & Напрями та види діяльності & Німеччина & Швеція & Франція & Польща \\
\hline I & Основна діяльність & & & & \\
\hline 1 & Послуги тренування & + / - (ШП) & + / - (ШП) & + / - (ШП) & + / - (ШП) \\
\hline 2 & Послуги катання на конях & $+1-$ & $+1-$ & $+1-$ & $+1-$ \\
\hline 3 & Послуги навчання верхової їзди & $+/-(Ш К B)$ & $+/-$ & $+/-(Ш K B)$ & $+1-$ \\
\hline 4 & Послуги оренди клубних коней & $+1-$ & $+/-$ & $+1-$ & $+1-$ \\
\hline 5 & Послуги (пакет) пансіону для коней & + / - (ШП) & + / - (ШП) & + / - (ШП) & + / - (ШП) \\
\hline 6 & Послуги ветеринарного лікаря & $+/-$ & $+/-$ & $+1-$ & $+1-$ \\
\hline 7 & Послуги коняра & $+1-$ & $+1-$ & $+1-$ & $+1-$ \\
\hline 8 & Послуги вершника & $+1-$ & $+1-$ & $+1-$ & $+1-$ \\
\hline 9 & Послуги прокату амуніції, аксесуарів & $+1-$ & $+1-$ & $+1-$ & $+1-$ \\
\hline 10 & Послуги продажу амуніції, аксесуарів (магазин) & $+1-$ & $+1-$ & $+1-$ & $+1-$ \\
\hline 11 & $\begin{array}{l}\text { Послуги підготовки та тренування коней (ком- } \\
\text { плексно з урахуванням роботи коняра, верш- } \\
\text { ника, ветеринарного лікаря) }\end{array}$ & $+1-$ & $+1-$ & $+1-$ & $+1-$ \\
\hline 12 & Послуги з продажу коней & $+1-$ & $+1-$ & $+1-$ & $+1-$ \\
\hline 13 & $\begin{array}{l}\text { Організація та проведення кінноспортивних } \\
\text { турнірів, змагань, у тому числі міжнародних }\end{array}$ & + / - (ШП) & + / - (ШП) & + / - (ШП) & $+1-$ \\
\hline 14 & $\begin{array}{l}\text { Організація прогулянок (походів) на конях } \\
\text { (разові послуги) }\end{array}$ & $+1-$ & $+1-$ & $+1-$ & $+1-$ \\
\hline 15 & Організація святкових заходів за участю коней & $+/-$ & $+1-$ & $+1-$ & $+1-$ \\
\hline 16 & Послуги іпотерапії & $+1-$ & $+1-$ & $+1-$ & $+1-$ \\
\hline 17 & Кінні табори для дітей & + / - (ШП) & + / - (ШП) & + / - (ШП) & + / - (ШП) \\
\hline 18 & Кінні скачки (офіційно дозволений тоталізатор) & + / - (ШП, Д, ПБ) & + / - (ШП, Д, ПБ) & + / - (ШП, Д, ПБ) & + / - (ШП, Д, ПБ) \\
\hline$\|$ & Додаткова діяльність & & & & \\
\hline 19 & Послуги розміщення & $+1-$ & $+1-$ & $+1-$ & $+1-$ \\
\hline 20 & Послуги харчування & $+1-$ & $+1-$ & $+1-$ & $+/-$ \\
\hline 21 & Послуги паркування автомобілів & $+1-$ & $+1-$ & $+1-$ & $+1-$ \\
\hline 22 & $\begin{array}{l}\text { Послуги оренди приміщень, території під певні } \\
\text { заходи }\end{array}$ & $+1-$ & $+1-$ & $+/-$ & $+1-$ \\
\hline 23 & Послуги догляду за дітьми різного віку & $+1-$ & $+1-$ & $+1-$ & $+1-$ \\
\hline 24 & Іінші додаткові послуги & $+/-$ & $+/-$ & $+/-$ & $+/-$ \\
\hline
\end{tabular}

Примітки: ШП - широке поширення; Д - дохідні; ПБ - значні податкові надходження до бюджету; ШКВ - школи верхової їзди

чого бюджет недоотримує доходи, кінноспортивні клуби порушують закон і отримують доходи менші, порівняно 3 тими, які б вони мали офіційно. Також слід відмітити, що організація таких тоталізаторів не поширена в Україні, багато клубів не орієнтовані на порушення законодавства;

2) вказані країни пропонують певний перелік послуг за додатковим на- прямом діяльності. Їх склад аналогічний тому, що надають українські кінноспортивні клуби.

Висновки. Здійснено узагальнення та систематизацію основних напрямів діяльності кінноспортивних клубів в Україні та за кордоном. Представлена систематизація основних напрямів діяльності кінноспортивних клубів в Україні показала, що на сьогодні в країні іс- нують: 1) суб'єкти, задіяні за основною (в тому числі з організацією та проведенням кінноспортивних турнірів, змагань, як національних, так і міжнародних) та додатковою діяльністю (великі кінноспортивні клуби); 2) суб'єкти, які надають широкий спектр основних та додаткових послуг, але не займаються організацією та проведенням кінноспортивних турнірів, змагань, як націо- 
нальних, так і міжнародних (через відсутність критих майданчиків) (середні за масштабами діяльності кінноспортивні клуби); 3) суб'єкти, які надають вузький спектр послуг (клуби з невеликими обсягами діяльності).

Аналіз та систематизацію основних напрямів діяльності кінноспортивних клубів в інших країнах проведено на прикладі країн, які протягом останніх двадцяти років мали перемоги та були лідерами Олімпійських ігор з кінного спорту (Німеччина, Швеція, Франція, Польща). Встановлено, що кінноспортивні клуби цих країн, як і українські, пропонують послуги основного та додаткового напрямів діяльності. При цьому вагоме місце в їх фуннкціонуванні займають ті послуги, що забезпечують попит населення, дохідність (участь в тоталізаторах на скачках, які офріційно дозволені законодавством). Встановлено, що цей вид діяльності є важливим джерелом доходів як кінноспортивних клубів, так і бюджету країн. Можна констатувати, що адаптація кращого зарубіжного досвіду управління напрямами діяльності в Україні можлива за умов відповідного законодавчого та інституційного забезпечення. Зокрема, дохідний напрям участі кінноспортивних клубів у тоталізаторах на скачках потребує прийняття рішення на рівні державної влади щодо необхідності та можливості дозволу на такий вид діяльності. Розвиток організаційно-технічного потенціалу, необхідного для розширення масштабів діяльності кінноспортивних клубів, може бути реалізований за умови паритетного державно-приватного партнерства, зокрема: відкриття закладів 3 підготовки кадрів, відкриття та реконструкції іподромів тощо.

Перспективи подальших досліджень полягають у теоретичному та методичному обґрунтуванні сучасних змін та трансфрормації напрямів діяльності кінноспортивних клубів.

Конфлікт інтересів. Автор заявляє, що відсутній будь-який конфрлікт інтересів.

\section{ЛITEPATУPA}

1. Бюджет Украины теряет сотни миллионов гривен из-за запрета ставок на скач ках. Дата оновлення: 20.12.2019. https://368. media/2018/02/27/byudzhet-ukrainy-teryaetsotni-millionov-griven-iz-za-zapreta-stavok-naskachkah/ (дата звернення: 20.12.2019).
2. Детская школа верховой езды «Конюшня Бутенко». Дата оновлення: 20.12.2019. http:// www.butenko-stable.com.ua/ (дата звернення: 20.12.2019)

3. Конноспортивный комплекс «Магнат». Дата оновлення: 20.12.2019. http://magnat.in.ua/ kompleks (дата звернення: 20.12.2019).

4. Конно-спортивный клуб «Equides». Да-та оновлення: 20.12.2019. https://equides.com.ua/ uroki-verhovoj-ezdy/ (дата звернення: 20.12.2019)

5. Конно-спортивный комплекс «Parade Allure». Дата оновлення: 20.12.2019. http://paradeallure.com/about/ (дата звернення: 20.12.2019)

6. Конный спорт: олимпийский медальный зачёт. Дата оновлення: 20.12.2019. https:/ olympteka.ru/olymp/sport/profile/20.html (дата звернення: 20.12.2019)

7. Заклади культури, фрізичної культури і спорту України у 2017 році. Київ: Державна служба статистики України, 2018. 95 с.

8. КП «Київський іподром». Дата оновлення 20.12.2019. https://kyivaudit.gov.ua/vr/ka/company.nsf/(pdpredr)/00846346 (дата звернення 20.12.2019).

9. Нагнебельна А. Кінний спорт в Україн та світі: тоталізатори та перегони. Дата оновлення: 23.10.2019. https://logincasino.com.ua/ article/kinnii-sport-v-ukraiyni-ta-sviti-totalizatori-taperegoni60393.html (дата звернення: 23.10.2019)

10. Семейный конный клуб «DERGACHOV». Дата оновлення: 23.10.2019. http://dergachov. com/ (дата звернення: 23.10.2019)

11. Статистичний щорічник України за 2018 рік. Житомир: ТОВ «БУК-ДРУК», 2019. 482 с.

12. Ткачева ИВ. Экономики спортивного коневодства. Зоотехническая наука Беларуси 2016; 2: 310-318.

13. Hästsporten berikar hela Sverige. Дата оновлення: 23.10.2019. https://www.tidningenridsport.se/hastsporten-berikar-hela-sverige/ (дата звернення: 23.10.2019).

14. Strategia Rozwoju Polskiego Jeździectwa w latach 2019 - 2022. Дата оновлення: 23.10.2019. https://pzj.pl/sites/default/files/\%20Wersja $\% 20$ Ostateczna $\% 20 \% 20 \% 20$ STRATEGIA $\% 20$ R OZW O J \% 20 P O L S KIEG O \% 20 J E \% C 5\%B 9DZIECTWA \% 202019-2022\%20 Nowelizacja\%2026.09.2019\%20r.\%20\%20.pdf (дата звернення: 23.10.2019).

15. The French horse industry at present. Дата оновлення: 23.10.2019. https://www.cambridge.org/core/journals/advances-in-animal-bios ciences/article/french-horse-industry-at-present 19DAEE1CDE8EBF0521B114BD7D72F1620 (дата звернення: 23.10.2019)

16. Wincewicz-Bosy M. Łańcuch dostaw ośrodków jeździeckich jako szansa rozwoju małych i średnich przedsiębiorstw. International Journal of Management and Economics. 2011; 31: 351-364.

\section{LITERATURE}

1. The budget of Ukraine loses hundreds of millions of hryvnias due to the ban on betting on horse races. Update date:20.12.2019. https://368. media/2018/02/27/byudzhet-ukrainy-teryaet sotni-millionov-griven-iz-za-zapreta-stavok-naskachkah/ (application date: 20.12.2019).

2. Children riding school "Butenko Stable». Update date: 20.12.2019. http://www.butenkostable.com.ua/ (application date: 20.12.2019)

3. «Magnat» equestrian centre. Update date: 20.12.2019. http://magnat.in.ua/kompleks (application date: 20.12.2019).

4. «Equides» equestrian centre. Update date: 20.12.2019. https://equides.com.ua/urokiverhovoj-ezdy/ (application date: 20.12.2019)

5. "Parade Allure» equestrian centre. Update date: 20.12.2019. http://paradeallure.com/about/ (application date: 20.12.2019)

6. Equestrian sport: Olympic medal standings. Update date: 20.12.2019. https://olympteka.ru/ olymp/sport/profile/20.html (application date 20.12.2019)

7. Institutions of culture, physical culture and sports of Ukraine in 2017. Kyiv: State Statistics Service of Ukraine, 2018. 95 p.

8. KP «Kyiv Hippodrome». Update date 20.12.2019. https://kyivaudit.gov.ua/vr/ka/company.nsf/(pdpredr)/00846346 (дата звернення: 20.12.2019)

9. Nagnebelna A. Equestrian sport in Ukraine and the world: sweepstakes and races. Update date: 23.10.2019. https://logincasino.com.ua/ article/kinnii-sport-v-ukraiyni-ta-sviti-totalizatorita-peregoni60393.html (application date: 23.10 2019)

10. «DERGACHOV» family equestrian club. Update date: 23.10.2019. http://dergachov.com/ (application date: 23.10.2019)

11. Statistical Yearbook of Ukraine for 2018 Zhytomyr: TOV «BUK-DRUK», 2019. 482 p.

12.Tkacheva IV. The economics of sports horse breeding. Zootechnical science of Belarus 2016; 2: 310-318.

13. Hästsporten berikar hela Sverige. Дата оновлення: 23.10.2019. https://www.tidningenridsport.se/hastsporten-berikar-hela-sverige/ (дата звернення: 23.10.2019).

14. Strategia Rozwoju Polskiego Jeździectwa w latach 2019 - 2022. Дата оновлення: 23.10.2019 https://pzj.pl/sites/default/files/\%20 Wersja\%200stateczna $\% 20 \% 20 \% 20$ STRA-TEGIA\%20ROZWOJU \%20POLSKIEG0\%20JE\%C5\%B9DZIECTWA \%20 2019-2022\%20Nowelizacja\%2026.09.2019\%20 r.\%20\%20.pdf (дата звернення: 23.10.2019).

15. The French horse industry at present Дата оновлення: 23.10.2019. https://www.cambridge.org/core/journals/advances-in-animal-biosciences/article/french-horse-industry-at-present /9DAEE1CDE8EBF0521B114BD7D72F1620 (дата звернення: 23.10.2019).

16. Wincewicz-Bosy M. Łańcuch dostaw ośrodków jeździeckich jako szansa rozwoju małych i średnich przedsiębiorstw. International Journal of Management and Economics. 2011; 31: 351-364.

Надійшла 26.02.2020

\section{ІНФОРМАЦІЯ ПРО АВТОРА}

Шмаренкова Наталія https://orcid.org/, koroleva1988@ukr.net

Національний університет фізичного виховання і спорту України, 03150, Київ, вул. Фізкультури, 1.

\section{INFORMATION ABOUT THE AUTHOR}

Shmarenkova Natalya https://orcid.org/, koroleva1988@ukr.net

National University of Ukraine on Physical Education and Sport, 03150, Kyiv, Fizkul'tury str., 1. 